REFLECTIONS:

NEUROLOGY AND

THE HUMANITIES

Section Editor

Anne W. McCammon,

MD, FAAN

Ilena C. George, MD

Correspondence to

Dr. George:

ilena.george@yale.edu

\title{
All noble things
}

Connecticut knows from whales.

On our first weekend off together during our neurology residency, two of my co-residents and I wandered through the sea museum at Mystic Seaport. We were all still new to the area and to neurology, getting our sea legs in unfamiliar territory. Ducking low to enter the hold of one of the ships docked in the museum's marina, it was easy to picture the private lives of the sailors: squalid and cramped, without hope of privacy, driven by dreams of profit (or forced into indentured servitude by crushing debt from previous expeditions) or a longing for adventure. Perhaps we sympathized. After all, whaling might be the great metaphor for perpetual, sometimes fruitless, striving, and we had just moved to one of its major centers.

"We need to start thinking of ourselves as having arrived," my co-resident said, peering into the cupboard-sized cabins where the crew slept headto-head. My co-resident has a penchant for aphorisms and self-help guides, but his dedication to self-improvement was scientific in its precision: $\mathrm{He}$ created weighted averages of pros and cons whenever making an important decision. This was an ongoing concern among the three of us; while friends and peers were hitting adult milestones, we felt caught in a perpetual professional adolescence, rife with growing pains. Long-term planning still had so many question marks and, rather than advancing, our specialty demanded yet another year at the bottom of the hospital hierarchy. Who knew where we would be at the conclusion of residency, of fellowship, of the long season at sea. We had each given up something important to move here and start neurology residency and, especially at the beginning, it felt a little daunting to learn a new set of skills and navigate these unfamiliar waters. Plus, unlike intern year, most of our larger clinical challenges-the emergency department, the intensive care unit (ICU) - we would face alone. This was the start of the journey; we had not arrived.

Whale processing was brutal. Once a whale was spotted, small teams would hunt down the animal and drag the carcass back to the ship, where the fat was stripped off in giant sheets-a process called flensing - then rendered extensively, and the whale oil was stored in vats below deck. The in-between times were onerous and the failures must have weighed heavily on the crew. Residency was always on my mind, and imagining the sailors abruptly being thrown into action made me think of stroke codesthe need for quick and accurate evaluation, then decisive action.

I was the last in my residency class to give tissue plasminogen activator (tPA) — a fact only I was aware of, but this awareness was a keen one-my personal white whale. With every stroke code I responded to, I wondered whether this would be the one: Would this patient be within the window? Would he or she have been on anticoagulants? What was his or her risk of bleeding if we gave tPA? Was anyone available to corroborate when he or she was last known well or speak on the patient's behalf? I have vivid memories of frantic phone calls to housekeepers, aides, and nursing home staff, trying to piece together a coherent story of what happened before the patient arrived at the hospital.

While the first time I pushed tPA was anticlimactic, the second time was the kind of case we all hope to recognize and intervene on quickly: a 26-year-old woman, a week postpartum, with a dense left middle cerebral artery stroke. On arrival, she was able to answer some simple questions but only with effort, and I tracked down her husband to confirm the time she was last seen normal. There is another version of me, one who only appears in the hospital, and it is she who is capable of asking invasive questions while faced with another person's profound distress. As a nonmedical friend pointed out, a day at the office for us is the worst day of someone else's life; there are days I feel that more acutely than others.

The husband relayed that she had been symptomfree less than three hours before arrival. We gave tPA. Maybe, I thought, as I pushed the bolus in slowly, she would be one of the lucky few who recovered quickly with intervention. Then she seized. I was asking her questions when awareness left her face and her arms came up in a classic figure four position. There was an emergent intubation and a subsequent flurry of activity leading to an ICU admission. Among me, my fellow, my attending, and the emergency room 
team, everything moved like clockwork, as fluid as hauling a rope in, hand over hand. It was exhilarating and then, abruptly, exhausting. At the end of my direct involvement, after my patient had been wheeled away to the ICU, I stood in the trauma bay, surveying the detritus on the floor and feeling as though even victory had a price.

My attending found me later that day. While I do not believe in the hospital superstition about certain people having black clouds following them, if ever someone truly did have a black cloud, it was she. "You and I have had some tough cases together," she said, "Let me know if you want to debrief." With the attention the medical community has started to pay physician burnout, debriefing was something of a buzzword at the time; talking through challenging cases was part of the effort to stave off depersonalization. Graduating medical school does not quite prepare you for mentally reconciling the contradiction inherent in treating patients, especially in the acute setting: You will hurt people, or watch them suffer. It is difficult not to feel as though you are doing something wrong, even while giving someone his or her best chance. In this case, there were no true adverse events but what was by all rights a good outcome still left a young person disabled, and it was difficult not to feel complicit in some inchoate way.

When I left the hospital that night, my coresidents decided it was time to plan our Thanksgiving menu (it was still August at the time), and had ordered a massive quantity of takeout in preparation. In different ways it had been a long day for all three of us, and since the beginning we have had an unspoken pact that we would face these difficulties together. Not long before, we had been strangers, and in a context other than residency, perhaps we would not have been friends. But here we were shipmates and surrogate family members, the products of a rare and elusive alchemy. I had not arrived, but I was not alone.

Back in Mystic Seaport, there were signs advertising an exhibit on measuring longitude and its importance for navigation at sea, but when we looked for it, a museum guide told us it would not open for several more weeks. "You should come back when we have our 24-hour reading of Moby Dick," she said. I could picture my co-residents and I, sitting on lawn chairs next to the fleet of once-great sailing vessels docked at the Seaport, listening to the sorts of people who spend 24-plus hours reading Melville aloud, and I could not help thinking: "Yeah, maybe we will." 


\title{
Neurology
}

\author{
All noble things \\ Ilena C. George \\ Neurology 2017;89;636-637 \\ DOI 10.1212/WNL.0000000000004198
}

This information is current as of August 7, 2017

\section{Updated Information \& Services}

\section{Subspecialty Collections}

Permissions \& Licensing

\section{Reprints}

including high resolution figures, can be found at: http://n.neurology.org/content/89/6/636.full

This article, along with others on similar topics, appears in the following collection(s):

\section{Clinical neurology examination}

http://n.neurology.org/cgi/collection/clinical_neurology_examination

Information about reproducing this article in parts (figures,tables) or in its entirety can be found online at:

http://www.neurology.org/about/about_the_journal\#permissions

Information about ordering reprints can be found online:

http://n.neurology.org/subscribers/advertise

Neurology ${ }^{\circledR}$ is the official journal of the American Academy of Neurology. Published continuously since 1951, it is now a weekly with 48 issues per year. Copyright () 2017 American Academy of Neurology. All rights reserved. Print ISSN: 0028-3878. Online ISSN: 1526-632X.

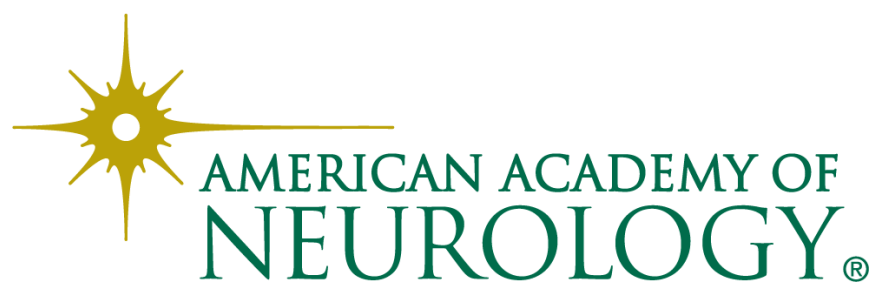

